\title{
Endocannabinoid-Dependent Long-Term Depression in a Nociceptive Synapse Requires Coordinated Presynaptic and Postsynaptic Transcription and Translation
}

\author{
Sharleen Yuan and Brian D. Burrell \\ Division of Basic Biomedical Sciences, Neuroscience Group, Sanford School of Medicine, University of South Dakota, Vermillion, South Dakota 57069
}

Endocannabinoids (eCBs) play an important role in long-term regulation of synaptic signaling in both vertebrates and invertebrates. In this study, the role of transcription- and translation-dependent processes in presynaptic versus postsynaptic neurons was examined during eCB-mediated synaptic plasticity in the CNS of the leech. Low-frequency stimulation (LFS) of non-nociceptive afferents elicits eCB-dependent long-term depression (eCB-LTD) heterosynaptically in nociceptive synapses that lasts at least $2 \mathrm{~h}$. Bath application of emetine, a protein synthesis inhibitor, blocked eCB-LTD after afferent LFS or exogenous eCB application, indicating that this depression was translation dependent. Bath application of actinomycin D, an irreversible RNA synthesis inhibitor, or 5,6-dichlorobenzimidazole 1- $\beta$-D-ribofurandoside (DRB), a reversible RNA synthesis inhibitor, also prevented eCB-LTD. Selective injection of DRB or emetine into the presynaptic or postsynaptic neuron before LFS indicated that eCB-LTD required transcription and translation in the postsynaptic neuron but only translation in the presynaptic cell. Depression observed immediately after LFS was also blocked when these transcription- and translation-dependent processes were inhibited. It is proposed that induction of eCB-LTD in this nociceptive synapse requires the coordination of presynaptic protein synthesis and postsynaptic mRNA and protein synthesis. These findings provide significant insights into both eCB-based synaptic plasticity and understanding how activity in non-nociceptive afferents modulates nociceptive pathways.

\section{Introduction}

Endocannabinoids (eCBs), such as 2-arachydonoyl glycerol (2AG) and anandamide, are lipid neurotransmitters known to elicit both short- and long-term synaptic plasticity (Heifets and Castillo, 2009). Generally, eCB synthesis and release is activity dependent, occurring in the postsynaptic neuron with subsequent retrograde transmission to the presynaptic cell, in which neurotransmitter release is depressed (Chevaleyre et al., 2006; Heifets and Castillo, 2009). Endocannabinoid-dependent long-term depression (eCB-LTD) is often mediated by the cannabinoid 1 $\left(\mathrm{CB}_{1}\right)$ receptor (Devane et al., 1988). However, recent studies have found that transient receptor potential vanilloid (TRPV) channels can also elicit eCB-mediated depression in the mammalian hippocampus, superior colliculus, nucleus accumbens, and the leech nervous system (Di Marzo et al., 2001; Gibson et al., 2008; Maione et al., 2009; Tóth et al., 2009; Chávez et al., 2010;

\footnotetext{
Received Aug. 16, 2012; revised Jan. 1, 2013; accepted Jan. 9, 2013.

Author contributions: S.Y. and B.D.B. designed research; S.Y. performed research; S.Y. analyzed data; S.Y. and B.D.B. wrote the paper.

This research was supported by National Science Foundation Grant IOS-1051734 (B.D.B.) and National Institute of Neurological Disorders and Stroke Grant F31 NS074473 (S.Y.). We thank Drs. Kevin Crisp and Brenda Moss for their editorial assistance during the preparation of this manuscript.

The authors declare no competing financial interests.

Correspondence should be addressed to Dr. Brian D. Burrell, Division of Basic Biomedical Sciences, Sanford School of Medicine, University of South Dakota, 414 E. Clark Street, Basic Biomedical Sciences, Lee Med Building, Vermillion, SD 57069. E-mail: bburrell@usd.edu.

DOI:10.1523/JNEUROSCI.3922-12.2013

Copyright $\odot 2013$ the authors $\quad 0270-6474 / 13 / 334349-10 \$ 15.00 / 0$
}

Grueter et al., 2010; Yuan and Burrell, 2010, 2012; Li and Burrell, 2011). Although presynaptic (Gibson et al., 2008; Maione et al., 2009; Yuan and Burrell, 2010) and postsynaptic (Chávez et al., 2010; Grueter et al., 2010) TRPV receptors have been observed to mediate eCB-LTD, increased intracellular $\mathrm{Ca}^{2+}$ and activation of calcineurin appear to be required in both instances (Chávez et al., 2010; Jensen and Edwards, 2012; Yuan and Burrell, 2012).

Previously, our laboratory has observed a heterosynaptic form of eCB-LTD in the CNS of the leech in which low-frequency stimulation (LFS) of a single touch (T)-sensitive neuron elicits a depression in a nociceptive $(\mathrm{N})$ neuron synapse (Yuan and Burrell, 2010). This is observed where the T-and N-cells converge onto the same postsynaptic target (Fig. 1a), the longitudinal (L) motor neuron that innervates the longitudinal muscle fibers involved in the leech's defensive shortening reflex (Shaw and Kristan, 1995). These features resemble gate control of pain, in which non-nociceptive afferent activity attenuates nociceptive signaling (Melzack and Wall, 1965). In addition to $\mathrm{Ca}^{2+}$ and calcineurin signaling, eCB-LTD in this $\mathrm{N}$ synapse requires postsynaptic 2-AG synthesis, 5-HT receptor activation, and activation of a presynaptic TRPV-like receptor (Yuan and Burrell, 2010, 2012). All protostomal and most deuterostomal invertebrates lack $\mathrm{CB}_{1}$ and $\mathrm{CB}_{2}$ receptors (Elphick and Egertova, 2005; Elphick, 2012), and central TRP channels may function as the invertebrate eCB receptor.

Although protein synthesis is critical for other forms of LTD (Huber et al., 2001), there have been very few studies of translational and transcriptional mechanisms contributing to eCB-LTD 
(Yin et al., 2006; Adermark et al., 2009) and none concerning TRPV-mediated depression. In this study, we took advantage of the ability to perform paired intracellular recordings from identifiable presynaptic $\mathrm{N}$ afferent cells and postsynaptic motor neurons in isolated leech ganglia to examine the translation- and transcriptiondependent processes mediating eCB-LTD. We observed that induction of eCB-LTD requires transcription-dependent processes in the postsynaptic neuron, whereas translation-dependent processes were required in both the presynaptic and postsynaptic cells. The findings from these experiments indicate that a coordinated series of mRNA- and protein-synthesisdriven processes is required for the induction of eCB-LTD.

\section{Materials and Methods}

Animal preparation. Leeches, weighing $3 \mathrm{~g}$ (the hermaphroditic species Hirudo verbana), were obtained from two commercial suppliers (Leeches USA and Niagara Medicinal Leeches) and maintained in artificial pond water $(0.52 \mathrm{~g}$ Instant Ocean $/ \mathrm{L} \mathrm{H}_{2} 0$ ). The animals were kept on a $12 \mathrm{~h} \mathrm{light/dark}$ cycle at $18^{\circ} \mathrm{C}$. Midbody ganglia were dissected and placed in a $1 \mathrm{ml} \mathrm{re-}$ cording chamber with constant perfusion (2 $\mathrm{ml} / \mathrm{min}$ ). Dissections and recordings were performed in normal leech saline (in $\mathrm{mm}: 110$ $\mathrm{NaCl}, 4 \mathrm{KCl}, 1.8 \mathrm{CaCl}_{2}, 1 \mathrm{MgCl}_{2}, 5 \mathrm{NaOH}$, and 10 HEPES, pH 7.4). The following drugs were obtained from Sigma-Aldrich: emetine, acti-

nomycin $\mathrm{D}$, and 5,6-dichlorobenzimidazole 1- $\beta$-D-ribofurandoside (DRB). 2-AG was obtained from Tocris Bioscience. Drugs for were dissolved in saline solution from frozen stock aliquots on the day that the experiments were conducted. Vehicle control experiments were performed using $0.01 \%$ dimethylsulfoxide (DMSO). All drugs used are membrane permeable, although our results indicate that it is possible to selectively inject these drugs into individual neurons without leak of sufficient concentrations to affect nearby cells.

Electrophysiology. Current-clamp (bridge balanced) intracellular recordings were made using sharp glass microelectrodes (25-40 M $\Omega$ ) fabricated from borosilicate capillary tubing ( $1.0 \mathrm{~mm}$ outer diameter, 0.75 $\mathrm{mm}$ inner diameter; FHC) using a horizontal puller (Sutter Instruments P-97). The microelectrodes were filled with $3 \mathrm{M} \mathrm{K}^{+}$acetate, and individual neurons were impaled by a manual micropositioner (model 1480; Siskiyou). Current pulses were delivered to the microelectrodes via a programmable stimulator (STG 1004; Multi-Channel Systems), and signals were recorded using a bridge amplifier (BA-1S; NPI). The signals were digitally converted (Digidata 1322A analog-to-digital converter) for observation and analysis (Axoscope; Molecular Devices).

Identification of individual cells was based on their position and action potential shape. Both the $\mathrm{T}$ and $\mathrm{N}$ neurons are located on the ventral side of the ganglion, whereas the $\mathrm{L}$ neuron is found on the dorsal side (Nicholls and Baylor, 1968). Ganglia were pinned dorsal side up in the recording chamber to allow recordings from the L motor neuron, the lateral T-cell, and the lateral N-cell. Identification of the motor neuron was confirmed through recordings from its electrically coupled homolog on the contralateral side.

Heterosynaptic LTD of the N synapse was elicited by LFS of the nonnociceptive T-cell at $1 \mathrm{~Hz}$ for $900 \mathrm{~s}$ (15 min). Recordings of the N-to-L synapse were made before the LFS (pretest), whereas posttest recordings were made at different time points (immediately after LFS, $30 \mathrm{~min}$ after LFS, 60 min after LFS, or $120 \mathrm{~min}$ after LFS) depending on the experi- ment (Figs. 1b, 2c). Separate electrode impalements of the same lateral $\mathrm{N}$ sensory cell and L motor neuron were made for pretest and posttest recordings, and no cell was impaled more than twice. Chronic intracellular recordings of these neurons were not performed because this results in progressive rundown of the EPSP within 10-15 min most likely because of damage caused by movements of the tissue during the electrode impalement (there are muscle fibers and connective tissue present in the leech CNS). Therefore, separate intracellular recordings were made during the pretest and posttest. Input resistance was recorded at the pretest and posttest level, and only consistent, stable recordings were included in the data analysis (input resistance with changes $<10 \%$ of the original pretest recording). When all the synapses tested in this study were averaged, the pretest input resistance was $23 \pm 2.3 \mathrm{M} \Omega$, and the post-test input resistance was $23 \pm 2.5 \mathrm{M} \Omega$. The peak EPSP amplitude was recorded every $10 \mathrm{~s}$ and calculated by averaging 10-20 EPSP (pretest or posttest) sweeps.

Drugs were applied through a gravity-fed superfusion beginning $2 \mathrm{~min}$ before LFS and last through the entire $15 \mathrm{~min}$ LFS period or without LFS for $15 \mathrm{~min}$ during control experiments (vehicle control had $0.01 \%$ DMSO) in a $1 \mathrm{ml}$ recording chamber with constant perfusion $(2 \mathrm{ml} /$ $\mathrm{min})$. Iontophoretic injection of drugs was performed $5 \mathrm{~min}$ before LFS and consisted of $-1 \mathrm{nA}, 500 \mathrm{~ms}$ current pulses delivered at $1 \mathrm{~Hz}$. Based on our previous studies, this protocol is effective in delivering pharmacological agents to the synaptic regions of the presynaptic or postsynaptic neurons, such as EGTA, capsazepine, and calcineurin inhibitory peptide (Yuan and Burrell, 2010, 2012).

Statistics. Posttest EPSP amplitudes were normalized relative to pretest levels and presented as mean \pm SE. Statistical analyses using a ANOVA were performed to determine main effects with Newman-Keuls post hoc tests to confirm the ANOVA results. In situations in which data were used for multiple ANOVAs (e.g., no LFS controls), we used the procedure by Benjamini and Hochberg (1995) for controlling the false discov- 

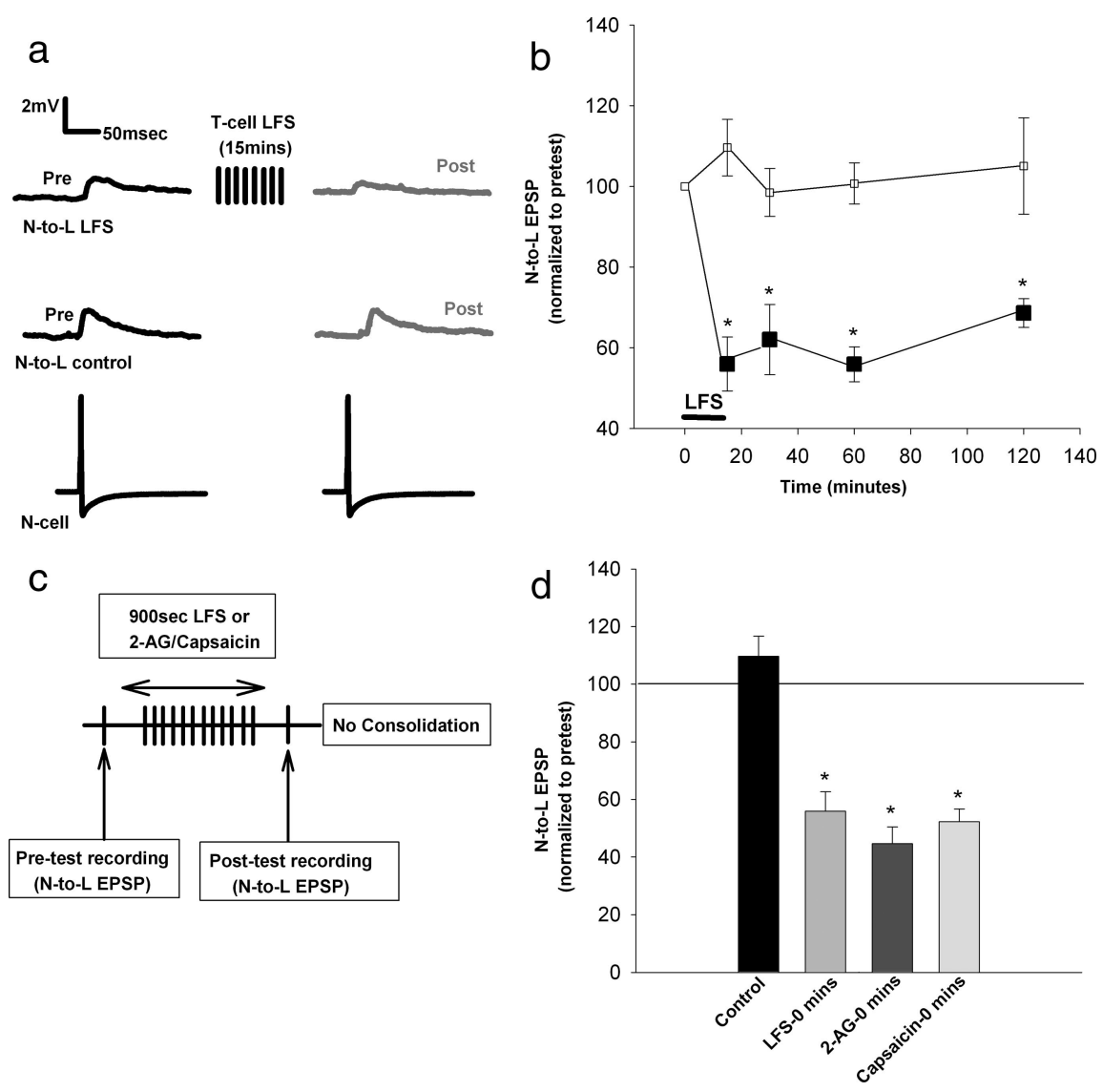

Figure 2. Time course of heterosynaptic eCB-LTD in the nociceptive synapse. $\boldsymbol{a}, \mathrm{N}$-to-L EPSPs before and after T-cell LFS (top). No depression was observed in control experiments in which the LFS was omitted (middle; black traces represent pretest EPSPS, and the gray traces represent the posttest EPSP recordings). Each EPSP was elicited by a single N-cell action potential (bottom). $\boldsymbol{b}$, Significant depression was observed at the $0,30,60$, and 120 min after LFS. ${ }^{*} p<0.01$, one-way ANOVA with Newman-Keuls post hoc analyses. Each time point in the control and LFS groups represents a separate group of synapses that were tested. $c$, Pretest recordings of the nociceptive synapse was followed by $15 \mathrm{~min}$ of LFS, 2-AG, or capsaicin treatment. Posttest recordings of the $\mathrm{N}$-to-L pathway occurred immediately after LFS or treatment had ended. $\boldsymbol{d}$, Bar graph representing nociceptive depression observed immediately after the $15 \mathrm{~min}$ LFS, 2-AG, or capsaicin treatment. Significant depression was observed in each treatment group compared to control data. ${ }^{*} p<0.001$, one-way ANOVA with Newman-Keuls post hoc. Data presented as normalized mean \pm SEM.

ery rate. When using a false discovery error rate of 0.05 , the $p$ values associated with the ANOVAs were still statistically significant. Analyses were performed with Statistica analysis software (Statsoft). All significance was evaluated at an $\alpha$ level of at least $p<0.05$.

\section{Results}

\section{Time course of depression}

As shown previously (Yuan and Burrell, 2010, 2012), LFS of the non-nociceptive T-cell induced significant depression of the nociceptive synapse when recorded $60 \mathrm{~min}$ after the LFS (Fig. 2a). However, it is not known how soon depression is observed after LFS and whether depression persists longer than $60 \mathrm{~min}$. Therefore, in separate groups of ganglia, synaptic transmission was measured immediately after LFS $(n=5)$, as well as $30 \min (n=$ $5), 60 \min (n=5)$, and $120 \min (n=6)$ after LFS and compared with controls in which LFS was omitted $(n=5$ for each time point). Significant depression was observed at all four time points (Fig. $2 b$; one-way ANOVA, $F_{(7,33)}=11.61 ; p=0.000007$; post hoc immediate vs control, $p=0.0002 ; 30 \mathrm{~min}, p<0.01 ; 60 \mathrm{~min}, p=$ 0.0019 ; and $120 \mathrm{~min}, p=0.0035)$. Significant depression in the nociceptive synapses was also observed immediately after a 15 min bath application of 2-AG $(100 \mu \mathrm{M})$ or capsaicin $(10 \mu \mathrm{M})$, treatments that have been shown previously to mimic activity- induced eCB-LTD (Yuan and Burrell, 2010, 2012) (Fig. 2d; one-way ANOVA, $F_{(3,16)}=24.09 ; p=0.000004$; post hoc immediate control vs immediate LFS, $p=$ 0.0002 vs $2-\mathrm{AG}, p=0.0002$ and vs capsaicin, $p=0.0002$; all $n=5$ ).

\section{LFS-induced depression requires translation and transcription}

To determine whether eCB-LTD in leech nociceptive synapses was translation dependent, ganglia were treated with emetine $(3 \mu \mathrm{M})$, the protein synthesis inhibitor that has been used in other invertebrate studies of synaptic plasticity (Villareal et al., 2007) and yeast protein regulation (Fewell and Woolford, 1999; Kaur and Bachhawat, 1999). When synaptic transmission was measured $60 \mathrm{~min}$ after LFS, bath application of emetine during 15 min LFS blocked LTD at the nociceptive synapse when compared with synapses in which LFS was delivered without emetine (Fig. $3 a ; F_{(3,15)}=5.31 ; p=$ 0.010737; post hoc control vs LFS, $p=0.0174$; LFS vs emetine + LFS, $p=$ 0.0118; control emetine vs LFS, $p=$ 0.0188 ; all $n=5$ ). Bath application of emetine for $15 \mathrm{~min}$ without LFS had no effect on the nociceptive synapse.

To test whether this synaptic depression is also mRNA synthesis dependent, actinomycin D (2 $\mu \mathrm{M})$, an irreversible RNA synthesis inhibitor that has been used in other invertebrate synaptic plasticity studies (Esdin et al., 2010), was applied during LFS. Application of actinomycin D during the LFS blocked depression in the nociceptive synapse (Fig. $3 b ; F_{(5,24)}=6.54 ; p=0.000572$; post hoc control vs LFS, $p<0.01$; LFS vs actinomycin D + LFS, $p<0.01$; all $n=5$ ) but had no effect on EPSP amplitude in control experiments in which actinomycin D was applied without LFS. These experiments were repeated with DRB $(150 \mu \mathrm{M})$, a reversible mRNA synthesis inhibitor that is effective in blocking transcription-dependent synaptic plasticity in other invertebrates and yeast (Greer and Greenberg, 2008; Zhou et al., 2009; Esdin et al., 2010). As with actinomycin D, DRB bath applied during LFS was found to block LFS-induced depression (Fig. $3 b ; F_{(5,24)}=6.54 ; p<0.000572$; post hoc control vs LFS, $p=$ 0.0009; LFS vs DRB + LFS, $p=0.0014$; all $n=5)$. DRB applied without LFS had no effect on synaptic transmission (post hoc analyses showed NS in control experiments). Therefore, it is concluded that activity-induced eCB-LTD in these nociceptive synapses is transcription and translation dependent.

\section{Presynaptic versus postsynaptic localization of transcription- and translation-dependent processes}

The above experiments were repeated using 2-AG $(60 \mu \mathrm{M})$. We showed previously that 2-AG can mimic and occlude LFSinduced eCB-LTD (Yuan and Burrell, 2010, 2012). Bath application of 2-AG for 15 min elicits depression in the N-cell synapse when measured $60 \mathrm{~min}$ after treatment. Previous studies suggest 
that 2-AG-induced depression is the result of a decrease in presynaptic neurotransmitter release (Yuan and Burrell 2010). The concentration of 2-AG used does not appear to have effects on the intrinsic membrane properties of the presynaptic or postsynaptic neurons given that input resistance of the postsynaptic L-cell after 2-AG treatment was $98.59 \pm 0.69 \%$ of pretreatment levels $(21.87 \pm 1.99$ vs $22.16 \pm 1.94$ $\mathrm{M} \Omega$ ), and the half-width N-cell action potential was $99.12 \pm 8.14 \%$ of pretreatment levels ( $4.78 \pm 0.55$ vs $4.60 \pm 0.34 \mathrm{~ms})$. However, it should be noted that these measurements were made from recordings at the soma and do not eliminate the possibility of changes membrane conductance in more distal regions of the cells.

Coapplication of 2-AG with the protein synthesis inhibitor emetine blocked this chemically induced LTD (Fig. 4a; $F_{(3,16)}=4.88 ; p=0.013497$; post hoc control vs $2-\mathrm{AG}, p=0.0234 ; 2-\mathrm{AG}$ vs emetine $+2-\mathrm{AG}, p=0.0154$; all $n=5$ ). These results indicate that $2-A G$-induced depression is protein synthesis dependent, consistent with what was observed during LFS-induced depression. However, depression after 2-AG treatment was not transcription dependent. Coapplication of 2-AG with either actinomycin D or DRB failed to block 2-AG-induced depression (Fig. $4 b ; F_{(5,24)}=11.48 ; p=0.00001$; post hoc control vs $2-\mathrm{AG}, p=0.0037$; actinomycin $\mathrm{D}$ control vs actinomycin $\mathrm{D}+2-\mathrm{AG}$, $p=0.0033$; DRB control vs DRB $+2-\mathrm{AG}$, $p=0.0012$; all $n=5$ ), a result that would appear to be inconsistent with the results observed during LFS-induced depression.

One explanation for this finding is that the requirement for new mRNA synthesis has been bypassed by the bath application of 2-AG. LFS-induced eCB-LTD of nociceptive synapses requires postsynaptic 2-AG synthesis (Yuan and Burrell, 2010). Therefore, it is possible that a transcription-dependent event related to synthesis or mobilization of 2-AG is required for activityinduced, 2-AG-mediated depression but is not required when depression is elicited chemically by the exogenous application of 2-AG. To test this hypothesis, DRB was selectively injected via iontophoresis into either the presynaptic nociceptive neuron or the postsynaptic motor neuron before LFS followed by a $60 \mathrm{~min}$ consolidation period. DRB injection into the postsynaptic motor neuron blocked LFS-induced depression, whereas presynaptic injection of DRB had no effect on this LTD (Fig. $5 a ; F_{(5,23)}=9.44$; $p=0.000054$; post hoc control vs LFS, $p=0.0031$; postsynaptic DRB + LFS vs LFS, $p=0.0005$; presynaptic DRB control vs presynaptic DRB + LFS, $p=0.0059$; all $n=5$ ). EPSP amplitudes were unchanged after control experiments in which DRB was injected into either the presynaptic or postsynaptic cell, but LFS was omitted (presynaptic and postsynaptic DRB controls showed no significant difference). In addition, the iontophoretic injection protocol by itself (without inclusion of any drug in the pinormalized mean \pm SEM.
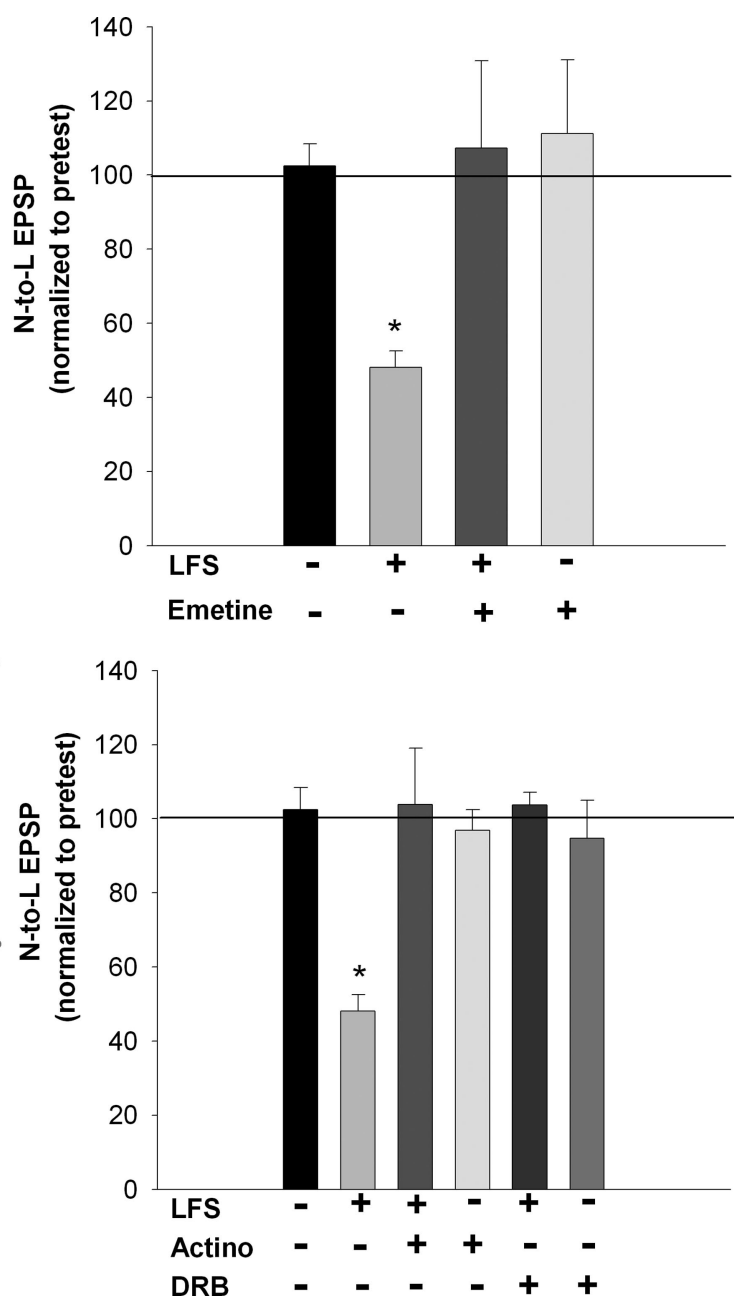

Figure 3. Protein and RNA synthesis is necessary for eCB-LTD in the nociceptive synapse (60 min posttest). $\boldsymbol{a}$, Left, Traces showng the decrease in EPSP amplitude after T-cell LFS in vehicle (0.01\% DMSO in saline), whereas no depression was observed when emetine was applied during LFS. Right, Bar graph comparing the effects on EPSP amplitude in the control, LFS, LFS + e, and emetine-treated groups. Depression normally observed after LFS treatment was blocked when emetine was applied (15 min) during LFS. Emetine alone had no effect. $\boldsymbol{b}$, Left, Traces showing a decrease in EPSP amplitude after LFS but no depression and DRB alone. Both actinomycin D and DRB blocked LFS-induced depression. No effect on EPSP amplitude was observed when actinomycin D or DRB was applied without LFS. ${ }^{*} p<0.01$, one-way ANOVA with Newman-Keuls post hoc. Data presented as

pette) did not alter LFS-induced depression of the nociceptive synapses $(70 \%$ decrease in synapses undergoing presynaptic iontophoresis and $65 \%$ decrease in synapses undergoing postsynaptic iontophoresis).

The above results are consistent with the idea that LFSinduced eCB-LTD requires RNA synthesis in the postsynaptic neuron and protein synthesis in both the presynaptic and postsynaptic neurons. To confirm the latter conclusion, LFS-induced depression experiments were repeated but with the protein synthesis inhibitor emetine injected into the presynaptic or postsynaptic neuron. Injection of emetine into either the presynaptic nociceptive neuron or the postsynaptic motor neuron blocked LFS-induced depression (at the $60 \mathrm{~min}$ posttest period; Fig. $5 b$; $F_{(4,20)}=14.54 ; p=0.00001 ;$ post hoc LFS vs presynaptic emetine + LFS, $p=0.000138$; LFS vs postsynaptic emetine + LFS, $p=$ 0.000206 ; LFS vs presynaptic emetine control, $p=0.000214$; LFS vs postsynaptic emetine control, $p=0.000195$; no significance between controls and injections; all $n=5$ ). EPSP amplitude re- 


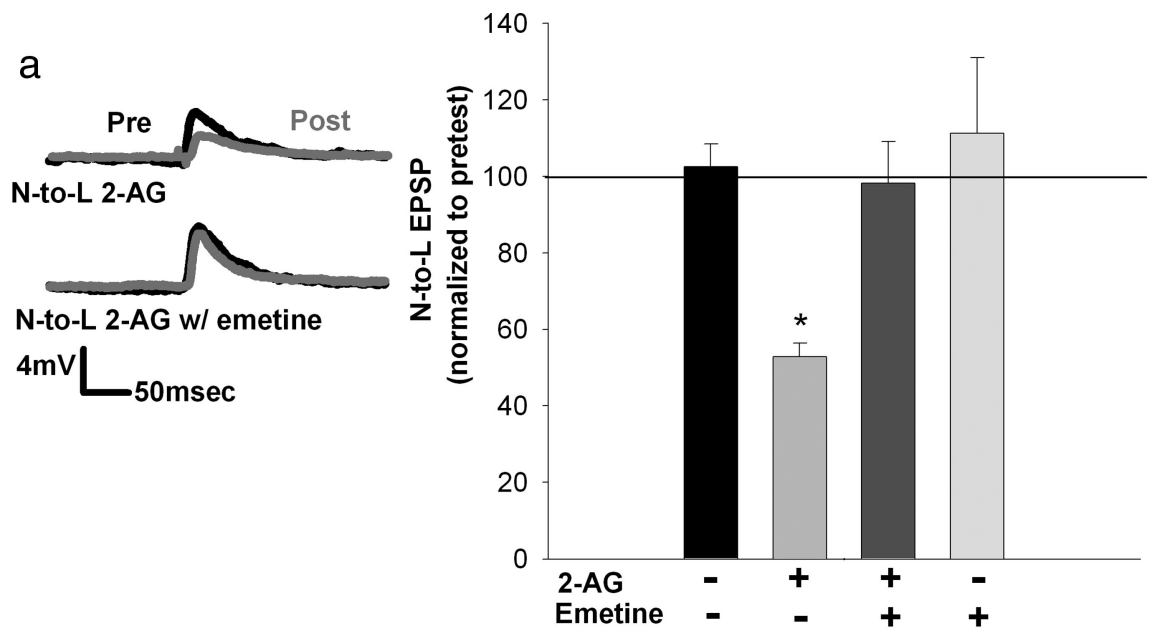

b

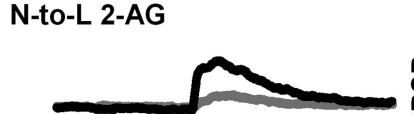

N-to-L 2-AG w/ actino

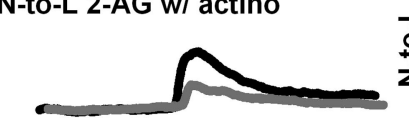

N-to-L 2-AG w/ DRB $4 \mathrm{mV} L 50 \mathrm{msec}$
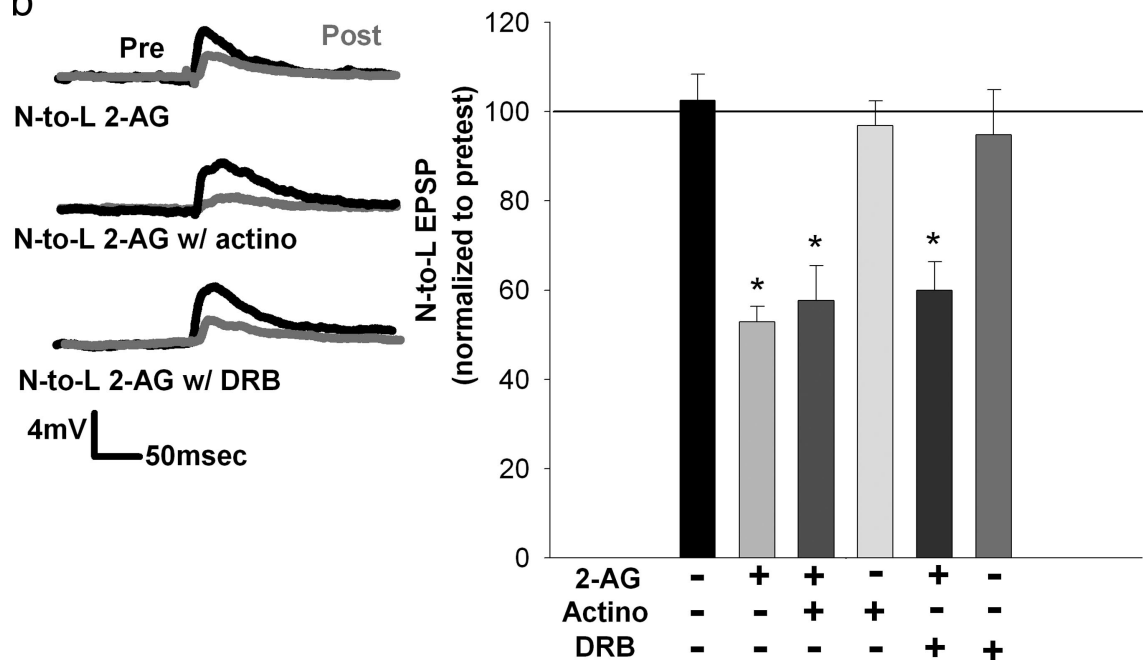

Figure 4. Protein, but not RNA synthesis, is necessary for 2-AG-induced depression in a nociceptive synapse (60 min posttest). $\boldsymbol{a}$, Left, Traces showing that the decrease in posttest EPSP amplitude normally observed after 2-AG treatment is blocked when emetine and 2-AG are coapplied. Right, Bar graph comparing the effects on EPSP amplitude after treatment with vehicle, 2-AG, 2-AG + emetine, or emetine alone. The depression normally observed after 2-AG treatment was blocked when 2-AG and emetine were coapplied. Emetine alone had no effect. $\boldsymbol{b}$, Left, Traces showing that 2-AG-induced depression was still observed when the eCB was coapplied with the transcription inhibitors actinomycin D (actino) and DRB. Right, Bar graph comparing the effects on EPSP amplitude after no treatment, 2-AG, 2-AG + actinomycin, actinomycin alone, 2-AG + DRB, and DRB alone. Both actinomycin D and DRB failed to block2-AG-induced depression. No effect on EPSP amplitude was observed when actinomycin D or DRB was applied without LFS. ${ }^{*} p<0.001(\boldsymbol{a})$ and ${ }^{*} p<0.01(\boldsymbol{b})$, one-way ANOVA with Newman-Keuls post hoc. Data presented as normalized mean \pm SEM.

mained unchanged during control experiments in which emetine was injected into the presynaptic or postsynaptic neuron without LFS. These findings indicate that, unlike RNA synthesis, protein synthesis is required at both the nociceptive and motor neurons during activity-induced eCB-LTD.

Injection of emetine in conjunction with bath application of 2-AG was also tested. Presynaptic emetine injection blocked 2-AG-induced depression, whereas postsynaptic emetine injection failed to inhibit depression (at the 60 min posttest period; Fig. $5 c ; F_{(4,20)}=45.151 ; p=0.00000000097$; post hoc $2-\mathrm{AG}$ vs presynaptic emetine $+2-\mathrm{AG}, p=0.000175 ; 2-\mathrm{AG}$ vs postsynaptic emetine $+2-\mathrm{AG}, p=0.373013$; presynaptic emetine $+2-\mathrm{AG}$ vs postsynaptic emetine $+2-\mathrm{AG}, p=0.000132$; postsynaptic emetine $+2-\mathrm{AG}$ vs postsynaptic emetine control, $p=0.00175$; presynaptic emetine $+2-\mathrm{AG}$ vs presynaptic emetine control, $p=0.238944$; all $n=5$ ). The lack of effect by postsynaptic emetine injection is consistent with the hypothesis that exogaptic neuron. enous application of 2-AG bypasses the contribution of transcription- and translation-dependent processes in the postsynaptic neuron that are required during LFS-induced forms of eCBLTD.

\section{Depression observed immediately after LFS requires transcription and translation}

As shown previously, there is significant depression immediately after LFS or 2-AG treatment. Is this early depression also transcription and translation dependent, or does new gene expression only contribute to depression observed at later time points? Emetine perfusion during LFS blocked depression normally observed immediately after LFS (Fig. $6 a ; F_{(3,17)}=$ $12.53 ; p=0.000173$; post hoc control vs immediate LFS, $p=0.0084$; immediate LFS vs immediate emetine + LFS, $p=$ 0.0005; all $n=5$ except emetine control, $n=6)$. When actinomycin D was applied, depression immediately after LFS was also inhibited, again similar to what is observed at the $60 \mathrm{~min}$ time point (Fig. $6 b ; F_{(3,16)}=$ $4.60 ; p=0.020693$, post hoc control vs immediate LFS, $p=0.0207$; immediate LFS vs immediate actinomycin $\mathrm{D}+\mathrm{LFS}, p=$ 0.0260 ; all $n=5$ except actinomycin $\mathrm{D}$ control, $n=6$ ). These findings indicate that depression immediately after LFS is also transcription and translation dependent.

Given that postsynaptic DRB injection blocked LFS-induced depression at the 60 min time point, indicating the necessity of RNA synthesis, this experiment was repeated for depression observed immediately after LFS. As with depression observed at the $60 \mathrm{~min}$ time point, DRB injected into the postsynaptic motor neuron abolished depression observed immediately after LFS, whereas presynaptic injection of DRB into the N-cell had no effect (Fig. $7 a ; F_{(5,23)}=14.99 ; p=$ 0.000002 ; post hoc control vs immediate LFS, $p=0.0003$; immediate LFS vs postsynaptic DRB + LFS, $p=0.0016$; presynaptic DRB + LFS vs postsynaptic DRB + LFS, $p=0.0002$; presynaptic DRB controls vs presynaptic DRB + LFS, $p=0.0002$; all $n=5$ except presynaptic DRB control, $n=4)$. EPSP amplitude was unchanged in control injections of DRB into either the presynaptic or postsynaptic neuron. These results suggest that, even immediately after LFS, RNA synthesis is necessary in the postsyn-

In terms of the role of protein synthesis, injection of emetine in either the presynaptic nociceptive neuron or the postsynaptic motor neuron prevented the depression normally seen immediately after LFS (Fig. $7 b ; F_{(4,20)}=19.46 ; p=0.000001$; post hoc immediate LFS vs presynaptic emetine + LFS, $p=0.000150$; immediate LFS vs postsynaptic emetine + LFS, $p=0.00182$; immediate LFS vs presynaptic emetine control, $p=0.000132$; immediate LFS vs postsynaptic emetine control, $p=0.000163$; no significance 
between controls and injections; all $n=5$ ). Therefore, these results indicate that protein synthesis is necessary in both the presynaptic and postsynaptic neurons, even at this early time period.

\section{Discussion}

New gene expression via both transcriptionand translation-dependent processes plays a critical role in eCB-LTD in nociceptive synapses after LFS of a non-nociceptive neuron. These findings are likely to have relevance beyond the leech CNS given the similarities that we have already documented with eCB-LTD in mammals, including the involvement of presynaptic TRPV-like receptors, presynaptic activation of calcineurin, postsynaptic eCB synthesis, and presynaptic and postsynaptic increases in intracellular $\mathrm{Ca}^{2+}$ (Gibson et al., 2008; Yuan and Burrell, 2010,2012; Jensen and Edwards, 2012). The ability to record from identifiable synapses in the leech CNS and manipulate signaling pathways in individual neurons is a powerful tool to identify critical cellular processes during synaptic plasticity and determine whether they operate presynaptically or postsynaptically.

Onset of synaptic depression was observed immediately after LFS (or 2-AG or capsaicin treatment) and persisted for at least $120 \mathrm{~min}$. LFS-induced eCB-LTD requires new protein synthesis in both the presynaptic nociceptive cell and the postsynaptic motor neuron based on experiments in which the translation inhibitor emetine was bath applied or intracellularly injected. This LTD was also found to require new RNA synthesis in the postsynaptic but not presynaptic neuron based on intracellular application of the transcription inhibitor DRB. Depression observed immediately after LFS also required postsynaptic RNA synthesis and presynaptic and postsynaptic protein synthesis.

When eCB-LTD was elicited by exogenous 2-AG, the resulting depression no longer required RNA synthesis (was not blocked by bath-applied actinomycin D or DRB) but was still protein synthesis dependent (was blocked by bath-applied emetine). Furthermore, 2-AG-induced depression required protein synthesis in the presynaptic, but not the postsynaptic, neuron based on emetine injection experiments. These differences between 2-AG- and activity-induced depression suggest that exogenous 2-AG bypasses the transcription- and translation-dependent processes in the postsynaptic neuron that are required for LFS-induce depression. An alternative explanation for these results is that different signaling pathways are mediating LFS- versus 2-AG-induced depression. This is unlikely given that $2-A G$ has been shown to occlude LFS-induced depression and that both 2-AG- and LFS-induced depression require activation of TRPV-like receptors and presynaptic calcineurin (Yuan and Burrell, 2010, 2012).

Based on these findings and the fact that eCB-LTD in these synapses requires postsynaptic 2-AG synthesis (Yuan and Burrell, 2010), it is likely that these postsynaptic transcription/ translation-dependent processes are related to the synthesis and/or retrograde transmission of 2-AG. Activity-induced gene transcription need not be of DAG lipase or the putative eCB transport protein directly but could involve a protein that regulates these processes. For example, homer $2 \mathrm{a}$ is known to play an important role in regulating DAG lipase activity related to eCBdependent synaptic plasticity (Jung et al., 2007; Roloff et al., 2010). In the case of the presynaptic neuron, translationdependent processes may be related to proteins that directly regulate neurotransmitter release (Chevaleyre et al., 2006) or to upstream molecules, such as calcineurin, that are known to be active in the presynaptic neuron during both $\mathrm{CB}_{1}$ - and TRPVmediated eCB-LTD (Heifets and Castillo, 2009; Jensen and Edwards, 2012; Yuan and Burrell, 2012).

To our knowledge, the only other studies of the potential roles of transcription and translation during eCB-LTD have been performed in the striatum (Yin et al., 2006; Adermark et al., 2009). In this region of the brain, presynaptic protein synthesis was found to be required for eCB-LTD, consistent with our findings. However, no role for postsynaptic transcription or translation was observed in striatal synapses, which clearly differs from the observations in the present study. One reason for these differences is 


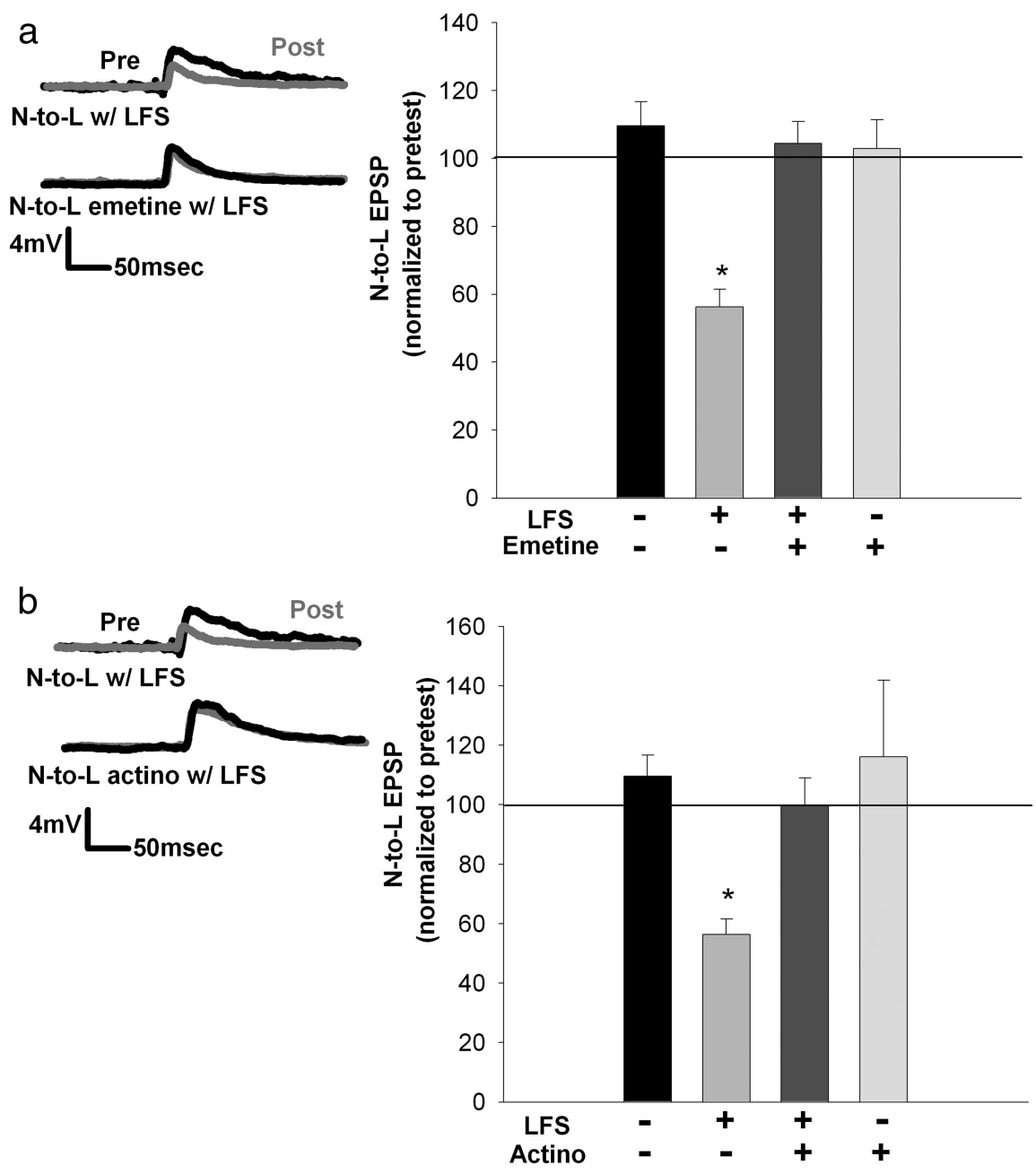

Figure 6. Protein and RNA synthesis are necessary for depression immediately after LFS. $\boldsymbol{a}$, Left, Traces showing that the depression observed immediately after T-cell LFS is blocked when emetine is applied during LFS. Right, Bar graph comparing the effects on EPSP amplitude after no treatment, LFS, LFS + emetine, and emetine alone. $\boldsymbol{b}$, Left, Traces showing that the depression observed immediately after T-cell LFS is blocked when actinomycin D (actino) is applied during LFS. Right, Bar graph comparing the effects on EPSP amplitude after no treatment, LFS, LFS + actinomycin D, and actinomycin D alone. Actinomycin D blocked depression immediately after LFS and had no effect on EPSP amplitude when applied without LFS. ${ }^{*} p<0.001$, one-way ANOVA with Newman-Keuls post hoc test Data presented as normalized mean \pm SEM.

that eCB-LTD was elicited heterosynaptically in the present study, whereas eCB-dependent depression in the striatum was elicited homosynaptically. Alternatively, these differences may reflect variability in the level of synaptic activity necessary to elicit eCB-LTD in different synapses (Heifets and Castillo, 2009). In the striatum, LFS for only $1-2 \mathrm{~min}$ is sufficient to elicit eCBdependent plasticity (Yin et al., 2006; Adermark et al., 2009), whereas LFS of 10 min or more has been used to elicit eCB-LTD in other synapses, including those in the leech (Heifets and Castillo, 2009; Alger and Kim, 2011). In previous studies, eCB-LTD in synapses made by $\mathrm{T}$ sensory neurons in the leech have shown that LFS $>7$ min was required to elicit eCB-LTD (Li and Burrell, 2009). These findings suggest that different synapses require different periods of activity to generate sufficient eCBs to induce long-lasting depression.

Synaptic depression observed immediately after the $15 \mathrm{~min}$ LFS also required both protein and RNA synthesis. This rapidly activating translation and transcription, although surprising, is not unprecedented in the context of synaptic plasticity (Feig and Lipton, 1993; Saha et al., 2011). Synaptically regulated local pro- tein synthesis occurs in both axonal (Van Minnen, 1994; Olink-Coux and Hollenbeck, 1996; Koenig and Giuditta, 1999) and dendritic (Tiedge and Brosius, 1996; Martin et al., 2000; Villareal et al., 2007; Bramham et al., 2010) compartments, and such localization of translational activity would support the rapid delivery of new proteins to synapses. In both the mammalian hippocampus and in Aplysia sensorimotor synapses, local protein synthesis was triggered through the activation of neurotransmitter receptors and induced synaptic plasticity within minutes (Huber et al., 2000; Villareal et al., 2007).

The requirement for rapid transcription in the postsynaptic cell indicates that a signal initiated in the distal regions must travel to the nucleus and stimulate mRNA synthesis, and then the resulting protein or mRNA transcript itself must travel back to the dendrite within the 15 min LFS window. This rapid rate of transcription in synaptic plasticity is not unprecedented given that activity-driven transcription of the immediate-early gene Arc, which is associated with various forms of synaptic plasticity, has been observed to occur within 5 min (Shepherd et al., 2006; Wibrand et al., 2006; Waung et al., 2008; Bramham et al., 2010; Saha et al., 2011). $\mathrm{Ca}^{2+}$ influx via voltage-gated $\mathrm{Ca}^{2+}$ channels (VGCCs) is known to initiate transcription in neurons (Lyons and West, 2011), and eCB-LTD in the leech does require activation of VGCCs and increases in postsynaptic $\mathrm{Ca}^{2+}$ ( $\mathrm{Li}$ and Burrell, 2010, 2011; Yuan and Burrell, 2012). The rate of mRNA transport in neuronal processes has been reported to be quite fast, with velocities of $0.4-4.5 \mu \mathrm{m} / \mathrm{s}$ being observed (Martin et al., 1997; Tiruchinapalli et al., 2003; Dictenberg et al., 2008; Tübing et al., 2010). Based on the known morphology of the postsynaptic L motor neuron in the leech (Nicholls and Purves, 1970), the distance between the soma and the points of synaptic contact is likely to be 200-300 $\mu \mathrm{m}$. Therefore, newly synthesized mRNAs could easily be delivered within the 15 min LFS period.

eCB-mediated neuromodulation regulates a wide range of brain functions, including learning and memory, appetite, anxiety, and pain; therefore, understanding the role of transcription and translation during eCB-dependent synaptic plasticity is critical. Although our findings are distinct from studies in the striatum (Yin et al., 2006; Adermark et al., 2009), this may reflect a difference in the threshold of activity necessary to elicit eCBLTD. eCB-LTD can be elicited by a variety of stimulation patterns, including short-duration $(<5 \mathrm{~min})$ or long-duration (10-15 $\mathrm{min})$ LFS, moderate stimulation $(10 \mathrm{~Hz})$, high-frequency stimulation $(50-100 \mathrm{~Hz})$, theta-burst stimulation, and spiketiming-dependent plasticity stimulation protocols (Heifets and Castillo, 2009; Alger and Kim, 2011). It is possible that the requirement for longer-duration activity to induce eCB-LTD may 
be attributable, in part, to a need for the new gene expression related to the synthesis and/or mobilization eCBs. This would imply that synapses in which only presynaptic translation is required, such as in the striatum, have a preexisting $\mathrm{eCB}$ "reservoir," either in terms of eCB-synthesizing capacity or possibly the eCB transmitters themselves (Alger and Kim, 2011).

Although not addressed in this study, TRPV receptors are also expressed in astrocytes and these glial cells have been shown to contribute to some forms of eCB-mediated synaptic plasticity, including instances in which eCBs elicit heterosynaptic modulation (Tóth et al., 2005; Navarrete and Araque, 2008, 2010; Han et al., 2012; Min and Nevian, 2012). In the leech CNS, neurons and their processes are actually contained within large glial cells (macroglia) that have many of the same functions as vertebrate astrocytes (Muller et al., 1981). It is unknown at this time whether these glia contribute to eCBmediated plasticity in the leech.

This study has important functional significance in terms of nociception. eCB-LTD was elicited heterosynaptically via LFS of the non-nociceptive touch afferents (T-cell). In mammals, stimulation of non-nociceptive $(\mathrm{A} \beta)$ afferents generates a decrease in nociceptive signaling, a process referred to as gate control of pain (Melzack and Wall, 1965). Gate control is traditionally thought to involve only GABAergic modulation (Melzack and Wall, 1965; D'Mello and Dickenson, 2008; Price et al., 2009), but spinal cord stimulation (SCS) and transcutaneous electrical nerve stimulation (TENS) studies indicate analgesic effects outlast the period of $A \beta$ afferent stimulation, suggesting the involvement of persistent modulatory processes (DeSantana et al., 2008; Pantaleão et al., 2011). eCBs have not been identified as contributing to gate control in mammals, but eCBs are known to have analgesic effects (Nyilas et al., 2009), are present in the spinal cord nociceptive circuitry, and their synthesis and mobilization in the spinal cord are stimulated by afferent stimulation (Hohmann et al., 2005). The present study not only supports the potential role of eCB-mediated synaptic modulation in gate control of pain but also provides evidence that the production of new gene products may contribute to the persistent analgesic effects observed after SCS or TENS. Understanding these transcriptional and translational processes will facilitate the use of eCBs for control of chronic pain.

\section{References}

Adermark L, Talani G, Lovinger DM (2009) Endocannabinoid-dependent plasticity at GABAergic and glutamatergic synapses in the striatum is regulated by synaptic activity. Eur J Neurosci 29:32-41. CrossRef Medline Alger BE, Kim J (2011) Supply and demand for endocannabinoids. Trends Neurosci 34:304-315. CrossRef Medline

Benjamini Y, Hochberg Y (1995) Controlling the false discovery rate: a practical and powerful approach to multiple testing. J R Stat Soc B Methods 57:289-300.

Bramham CR, Alme MN, Bittins M, Kuipers SD, Nair RR, Pai B, Panja D, Schubert M, Soule J, Tiron A, Wibrand K (2010) The Arc of synaptic memory. Exp Brain Res 200:125-140. CrossRef Medline

Chávez AE, Chiu CQ, Castillo PE (2010) TRPV1 activation by endogenous anandamide triggers postsynaptic long-term depression in dentate gyrus. Nat Neurosci 13:1511-1518. CrossRef Medline

Chevaleyre V, Takahashi KA, Castillo PE (2006) Endocannabinoidmediated synaptic plasticity in the CNS. Annu Rev Neurosci 29: 37-76. CrossRef Medline

DeSantana JM, Walsh DM, Vance C, Rakel BA, Sluka KA (2008) Effectiveness of transcutaneous electrical nerve stimulation for treatment of hyperalgesia and pain. Curr Rheumatol Rep 10:492-499. CrossRef Medline

Devane WA, Dysarz FA 3rd, Johnson MR, Melvin LS, Howlett AC (1988) Determination and characterization of a cannabinoid receptor in rat brain. Mol Pharmacol 34:605-613. Medline

Dictenberg JB, Swanger SA, Antar LN, Singer RH, Bassell GJ (2008) A direct role for FMRP in activity-dependent dendritic mRNA transport 
links filopodial-spine morphogenesis to fragile X syndrome. Dev Cell 14:926-939. CrossRef Medline

Di Marzo V, Bisogno T, De Petrocellis L (2001) Anandamide: some like it hot. Trends Pharmacol Sci 22:346-349. CrossRef Medline

D’Mello R, Dickenson AH (2008) Spinal cord mechanisms of pain. Br J Anaesth 101:8-16. CrossRef Medline

Elphick MR (2012) The evolution and comparative neurobiology of endocannabinoid signalling. Philos Trans R Soc Lond B Biol Sci 367: 3201-3215. CrossRef Medline

Elphick MR, Egertová M (2005) The phylogenetic distribution and evolutionary origins of endocannabinoid signalling. Handb Exp Pharmacol:283-297.

Esdin J, Pearce K, Glanzman DL (2010) Long-term habituation of the gillwithdrawal reflex in Aplysia requires gene transcription, calcineurin and L-type voltage-gated calcium channels. Front Behav Neurosci 4:181. CrossRef Medline

Feig S, Lipton P (1993) Pairing the cholinergic agonist carbachol with patterned Schaffer collateral stimulation initiates protein synthesis in hippocampal CA1 pyramidal cell dendrites via a muscarinic, NMDA-dependent mechanism. J Neurosci 13:1010-1021. Medline

Fewell SW, Woolford JL Jr (1999) Ribosomal protein S14 of Saccharomyces cerevisiae regulates its expression by binding to RPS14B pre-mRNA and to 18S rRNA. Mol Cell Biol 19:826-834. Medline

Gibson HE, Edwards JG, Page RS, Van Hook MJ, Kauer JA (2008) TRPV1 channels mediate long-term depression at synapses on hippocampal interneurons. Neuron 57:746-759. CrossRef Medline

Greer PL, Greenberg ME (2008) From synapse to nucleus: calciumdependent gene transcription in the control of synapse development and function. Neuron 59:846-860. CrossRef Medline

Grueter BA, Brasnjo G, Malenka RC (2010) Postsynaptic TRPV1 triggers cell type-specific long-term depression in the nucleus accumbens. Nat Neurosci 13:1519-1525. CrossRef Medline

Han J, Kesner P, Metna-Laurent M, Duan T, Xu L, Georges F, Koehl M, Abrous DN, Mendizabal-Zubiaga J, Grandes P, Liu Q, Bai G, Wang W, Xiong L, Ren W, Marsicano G, Zhang X (2012) Acute cannabinoids impair working memory through astroglial CB1 receptor modulation of hippocampal LTD. Cell 148:1039-1050. CrossRef Medline

Heifets BD, Castillo PE (2009) Endocannabinoid-signaling and long-term synaptic plasticity. Annu Rev Physiol 71:283-306. CrossRef Medline

Hohmann AG, Suplita RL, Bolton NM, Neely MH, Fegley D, Mangieri R, Krey JF, Walker JM, Holmes PV, Crystal JD, Duranti A, Tontini A, Mor M, Tarzia G, Piomelli D (2005) An endocannabinoid mechanism for stress-induced analgesia. Nature 435:1108-1112. CrossRef Medline

Huber KM, Kayser MS, Bear MF (2000) Role for rapid dendritic protein synthesis in hippocampal mGluR-dependent long-term depression. Science 288:1254-1257. CrossRef Medline

Huber KM, Roder JC, Bear MF (2001) Chemical induction of mGluR5- and protein synthesis-Dependent long-term depression in hippocampal area CA1. J Neurophysiol 86:321-325. Medline

Jensen T, Edwards JG (2012) Calcineurin is required for TRPV1-induced long-term depression of hippocampal interneurons. Neurosci Lett 510: 82-87. CrossRef Medline

Jung KM, Astarita G, Zhu C, Wallace M, Mackie K, Piomelli D (2007) A key role for diacylglycerol lipase- $\alpha$ in metabotropic glutamate receptor-dependent endocannabinoid mobilization. Mol Pharmacol 72:612-621. CrossRef Medline

Kaur R, Bachhawat AK (1999) The yeast multidrug resistance pump, Pdr5p, confers reduced drug resistance in erg mutants of Saccharomyces cerevisiae. Microbiology 145:809-818. CrossRef Medline

Koenig E, Giuditta A (1999) Protein-synthesizing machinery in the axon compartment. Neuroscience 89:5-15. CrossRef Medline

Li Q, Burrell BD (2009) Two forms of long-term depression in a polysynaptic pathway in the leech CNS: one NMDA receptor-dependent and the other cannabinoid dependent. J Comp Physiol A Neuroethol Sens Neural Behav Physiol 195:831-841. CrossRef Medline

Li Q, Burrell BD (2010) Properties of cannabinoid-dependent long-term depression in the leech. J Comp Physiol A Neuroethol Sens Neural Behav Physiol 196:841-851. CrossRef Medline

Li Q, Burrell BD (2011) Associative, bidirectional changes in neural signaling utilizing NMDA receptor- and endocannabinoid-dependent mechanisms. Learn Mem 18:545-553. CrossRef Medline

Lyons MR, West AE (2011) Mechanisms of specificity in neuronal activity- regulated gene transcription. Prog Neurobiol 94:259-295. CrossRef Medline

Maione S, Cristino L, Migliozzi AL, Georgiou AL, Starowicz K, Salt TE, Di Marzo V (2009) TRPV1 channels control synaptic plasticity in the developing superior colliculus. J Physiol 587:2521-2535. CrossRef Medline

Martin KC, Casadio A, Zhu H, Yaping E, Rose JC, Chen M, Bailey CH, Kandel ER (1997) Synapse-specific, long-term facilitation of aplysia sensory to motor synapses: a function for local protein synthesis in memory storage. Cell 91:927-938. CrossRef Medline

Martin KC, Barad M, Kandel ER (2000) Local protein synthesis and its role in synapse-specific plasticity. Curr Opin Neurobiol 10:587-592. CrossRef Medline

Melzack R, Wall PD (1965) Pain mechanisms: a new theory. Science 150: 971-979. CrossRef Medline

Min R, Nevian T (2012) Astrocyte signaling controls spike timingdependent depression at neocortical synapses. Nat Neurosci 15: 746-753. CrossRef Medline

Muller KJ, Nicholls JG, Stent GS, eds (1981) Neurobiology of the leech. Woodbury, NY: Cold Spring Harbor Laboratory.

Navarrete M, Araque A (2008) Endocannabinoids mediate neuronastrocyte communication. Neuron 57:883-893. CrossRef Medline

Navarrete M, Araque A (2010) Endocannabinoids potentiate synaptic transmission through stimulation of astrocytes. Neuron 68:113126. CrossRef Medline

Nicholls JG, Baylor DA (1968) Specific modalities and receptive fields of sensory neurons in CNS of the leech. J Neurophysiol 31:740-756. Medline

Nicholls JG, Purves D (1970) Monosynaptic chemical and electrical connexions between sensory and motor cells in the central nervous system of the leech. J Physiol 209:647-667. Medline

Nyilas R, Gregg LC, Mackie K, Watanabe M, Zimmer A, Hohmann AG, Katona I (2009) Molecular architecture of endocannabinoid signaling at nociceptive synapses mediating analgesia. Eur J Neurosci 29: 1964-1978. CrossRef Medline

Olink-Coux M, Hollenbeck PJ (1996) Localization and active transport of mRNA in axons of sympathetic neurons in culture. J Neurosci 16:13461358. Medline

Pantaleão MA, Laurino MF, Gallego NL, Cabral CM, Rakel B, Vance C, Sluka KA, Walsh DM, Liebano RE (2011) Adjusting pulse amplitude during transcutaneous electrical nerve stimulation (TENS) application produces greater hypoalgesia. J Pain 12:581-590. CrossRef Medline

Price TJ, Cervero F, Gold MS, Hammond DL, Prescott SA (2009) Chloride regulation in the pain pathway. Brain Res Rev 60:149-170. CrossRef Medline

Roloff AM, Anderson GR, Martemyanov KA, Thayer SA (2010) Homer la gates the induction mechanism for endocannabinoid-mediated synaptic plasticity. J Neurosci 30:3072-3081. CrossRef Medline

Saha RN, Wissink EM, Bailey ER, Zhao M, Fargo DC, Hwang JY, Daigle KR, Fenn JD, Adelman K, Dudek SM (2011) Rapid activity-induced transcription of Arc and other IEGs relies on poised RNA polymerase II. Nat Neurosci 14:848-856. CrossRef Medline

Shaw BK, Kristan WB Jr (1995) The whole-body shortening reflex of the medicinal leech: motor pattern, sensory basis, and interneuronal pathways. J Comp Physiol A Neuroethol Sens Neural Behav Physiol 177:667681. Medline

Shepherd JD, Rumbaugh G, Wu J, Chowdhury S, Plath N, Kuhl D, Huganir RL, Worley PF (2006) Arc/Arg3.1 mediates homeostatic synaptic scaling of AMPA receptors. Neuron 52:475-484. CrossRef Medline

Tiedge H, Brosius J (1996) Translational machinery in dendrites of hippocampal neurons in culture. J Neurosci 16:7171-7181. Medline

Tiruchinapalli DM, Oleynikov Y, Kelic S, Shenoy SM, Hartley A, Stanton PK, Singer RH, Bassell GJ (2003) Activity-dependent trafficking and dynamic localization of zipcode binding protein 1 and $\beta$-actin mRNA in dendrites and spines of hippocampal neurons. J Neurosci 23:32513261. Medline

Tóth A, Boczán J, Kedei N, Lizanecz E, Bagi Z, Papp Z, Edes I, Csiba L, Blumberg PM (2005) Expression and distribution of vanilloid receptor 1 (TRPV1) in the adult rat brain. Brain Res Mol Brain Res 135:162168. CrossRef Medline

Tóth A, Blumberg P, Boczán J (2009) Anandamide and the vanilloid receptor (TRPV1). Vitam Horm 81:389-419. CrossRef Medline

Tübing F, Vendra G, Mikl M, Macchi P, Thomas S, Kiebler MA (2010) 
Dendritically localized transcripts are sorted into distinct ribonucleoprotein particles that display fast directional motility along dendrites of hippocampal neurons. J Neurosci 30:4160-4170. CrossRef Medline

Van Minnen J (1994) RNA in the axonal domain: a new dimension in neuronal functioning? Histochem J 26:377-391. CrossRef Medline

Villareal G, Li Q, Cai D, Glanzman DL (2007) The role of rapid, local, postsynaptic protein synthesis in learning-related synaptic facilitation in Aplysia. Curr Biol 17:2073-2080. CrossRef Medline

Waung MW, Pfeiffer BE, Nosyreva ED, Ronesi JA, Huber KM (2008) Rapid translation of Arc/Arg3.1 selectively mediates mGluRdependent LTD through persistent increases in AMPAR endocytosis rate. Neuron 59:84-97. CrossRef Medline

Wibrand K, Messaoudi E, Håvik B, Steenslid V, Løvlie R, Steen VM, Bramham CR (2006) Identification of genes co-upregulated with Arc during BDNF-induced long-term potentiation in adult rat dentate gyrus in vivo. Eur J Neurosci 23:1501-1511. CrossRef Medline
Yin HH, Davis MI, Ronesi JA, Lovinger DM (2006) The role of protein synthesis in striatal long-term depression. J Neurosci 26:1181111820. CrossRef Medline

Yuan S, Burrell BD (2010) Endocannabinoid-dependent LTD in a nociceptive synapse requires activation of a presynaptic TRPV-like receptor. J Neurophysiol 104:2766-2777. CrossRef Medline

Yuan S, Burrell BD (2012) Long-term depression of nociceptive synapses by non-nociceptive afferent activity: role of endocannabinoids, $\mathrm{Ca}^{2+}$, and calcineurin. Brain Res 1460:1-11. CrossRef Medline

Zhou K, Kuo WH, Fillingham J, Greenblatt JF (2009) Control of transcriptional elongation and cotranscriptional histone modification by the yeast BUR kinase substrate Spt5. Proc Natl Acad Sci U S A 106:69566961. CrossRef Medline 